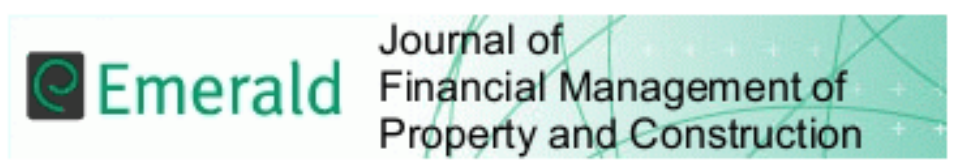

\title{
An investigation into BIM based detailed cost estimating and drivers to the adoption of BIM in quantity surveying practices
}

\begin{tabular}{|r|l|}
\hline Journal: & Journal of Financial Management of Property and Construction \\
\hline Manuscript ID & JFMPC-05-2019-0042.R2 \\
\hline Manuscript Type: & Research Paper \\
\hline Keywords: & $\begin{array}{l}\text { Building Information Modelling (BIM), Cost Estimating, global } \\
\text { competitiveness, Quantity Surveying, Nigeria }\end{array}$ \\
\hline \multicolumn{2}{|l}{} \\
\hline
\end{tabular}




\title{
An investigation into BIM based detailed cost estimating and drivers to the adoption of BIM in quantity surveying practices
}

\begin{abstract}
Purpose-Although studies have shown the relevance of BIM (Building Information Modeling) in cost estimating process, efforts at investigating BIM based detailed cost estimating among professional quantity surveyors through quantitative approach are scanty. The purpose of this study is to identify and examine the usage of BIM based detailed cost estimating software; and assesses the drivers to BIM adoption within the Nigerian quantity surveying consulting firms.
\end{abstract}

Design/methodology/approach- A comprehensive literature review, pilot study, and questionnaire survey were adopted. The survey targeted both the BIM users and non- BIM users' quantity surveying consulting firms in Lagos, Nigeria. The data collected were analysed using frequency, percentage, mean score, standard deviation, Mann-Whitney test, and factor analysis.

Findings-The study found that $46.58 \%$ of quantity surveying consulting firms are aware of BIM and have adopted it for detailed cost estimating, while $49.32 \%$ of quantity surveying consulting firms are aware but have not adopted BIM based detailed cost estimating, and $4.10 \%$ of quantity surveying consulting firms are not aware at all. Also, the study identified various BIM based detailed cost estimating software used in quantity surveying practices and found that Microsoft excel is often used alongside 3D software; Autodesk QTO, Navisworks, Innovaya composer, and CostX respectively are prevalent BIM software used for detailed cost estimating. In addition, the study identified 21 drivers to the adoption of BIM in quantity surveying practices. The result of factor analysis grouped the 21 identified drivers into five principal factors: improved whole life cycle/design quality; enhanced decision and visualization; cost and time saving; marketing and support for quantity surveyor tasks; and government and client pressure.

Practical implication-This study provides significant insight into the application of BIM to quantity surveying consulting practices, thereby enables consultant quantity surveyors to make informed decisions to select BIM cost estimating software to suit their practices. Further, the study findings can be useful for individuals, clients' and contractors' quantity surveyors to be fully aware of the opportunities BIM could bring in relation to their service delivery.

Originality/value-Accurate cost estimating, effective cost monitoring and control areessential elements to a construction project success. This study further emphasized the importance of BIM to quantity surveying practices, particularly in the area of the detailed cost estimating.

Keywords: BIM, cost estimating, global competitiveness, quantity surveying, Nigeria Paper type Research paper

\section{Introduction}

In order to remain globally competitive, quantity surveyors must be ready to adapt to any innovation in the construction industry. In recent times, there has been different innovations in the construction industry ranging from augmented reality, construction software and data ecosystem, to building information modeling (BIM) amongst others. The evolution of these innovations has brought the development of different tools, techniques and software to enhance productivity among construction professionals. In the last decade, BIM is one of the technologies trending in the construction industry (Kulasekaraet al., 2013). BIM is described as a process of 
producing, managing, storing, exchanging and sharing building information in an interoperable way (Yan and Damian, 2008). This automation explored by the use of BIM has helped increase efficiency in cost estimating among others (Afoluhai, 2012).

Detailed cost estimating is a very important aspect of quantity surveying profession, to be precise. It is the most essential knowledge a quantity surveying practitioner must possess, either working as a contractor or consultant quantity surveyor. A quantity surveying practitioner must possess an excellent skill in quantity take off and building of rates. Ismail (2016) stated that cost estimating is the most important quantity surveying skill in determining construction project costs. It involves the prediction of the most likely cost of a construction project which depends on a number of variables which are materials, labour, plant, profit and overhead. As a project becomes complex, the whole process of estimating becomes enormous and time consuming, and with the growing competition in the industry and the increasing demands of clients for value for money, accuracy and efficiency, the quantity surveyor competence to carry out estimating operations traditionally becomes questioned.Shen and Issa (2010) argued that generating a detailed cost estimate is very important butit is a time consuming task in construction projects. For instance, in preparing detailed cost estimates, most of the time is spent on visualization, interpretation, clarification of drawings, specification information and aggregated quantities of labour, materials and equipment. As a result of this, cost estimates provided by quantity surveyors are arguably producing errors and inaccuracies due to unmanageable circumstances.

However, BIM has presented to solve estimating operations. For instance, Thurairajah and Gruchor (2013) asserted that BIM is crucial when it comes to accurate and reliable cost estimating. This is affirmed by Sattineni and Harrison (2014) who indicated that quantity takeoff automation is one of the capabilities of BIM which reduces time and cost required in preparing cost estimates. In addition, previous studies on BIM have shown that BIM offers a better advantage by improving the estimating practices that are usually prone to errors (Olatunji and Sher, 2010; Azhar, 2011; Eastman et al., 2011) among others. For instance, Attar et al. (2013) found that by adopting BIM, 80\% reduction in time to prepare estimates and 10\% savings on construction cost through clash detection were attainable. In addition, Olatunji and Sher (2015) argued that there are limited empirical tools upon which modern construction estimating theories could be based. However, with the emergence of BIM for estimating, there is need for research on the advances in BIM (Olatunji and Sher, 2015). This triggered several studies on BIM in relation to quantity surveying practices. For instance, studies like application of 5D BIM including its benefits and challenges (see Olatunji et al., 2010; Cheunga et al., 2012; Frei et al., 2013; Wu et al., 2014; Luth et al., 2014; Wong and Yew, 2017; Olawumi and Chan, 2018). Few studies focused on the role of quantity surveyors in developing 5D BIM (Smith, 2016; Mayoufet al., 2019). Few studies on BIM education in quantity surveying (see Ali et al., 2015; Babatunde et al., 2018; Babatunde and Ekundayo, 2019). Other studies on BIM enabled estimating (see Olatunji and Sher, 2014; Olatunji and Sher, 2015) among others.

Despite these previous studies, there is limited empirical study on the investigation of the use of BIM for detailed cost estimating among quantity surveying consulting firms. Since cost estimating is a core duty of quantity surveyors and there is a gap in analyzing the factors influencing the adoption of BIM in quantity surveying consulting firms, particularly in developing countries. Therefore, this study becomes imperative with a view to identifying and examining the usage of BIM based detailed cost estimating software and assessing the drivers to the adoption of BIM in quantity surveying consulting firms. 


\section{Literature review}

\section{Concept of BIM}

The drive to develop 3D modeling arose from the urge to develop accurate construction details of building designed in complex form (Boon, 2009). The concept of BIM started in the 1990's and BIM has presented so many opportunities to the construction industry. BIM has evolved from being just a software to an integrating system. BIM does not present itself as software, instead it is an information technology (IT) solution for integrating software application, and IT tools to design a building in a common platform which is not dependent on the software used (Jayasena and Neddikkara, 2012). The evolution of BIM has caused drastic change in the way operations are being carried out in the industry. Olatunji and Sher (2015) stated that BIM stores robust quantitative and qualitative data. Thus, BIM enables the estimators to export unto dedicated platforms for costing, without substantial additional calculations on the quantification of design attributes. The basic concept of BIM is hinged on the need to provide a platform that provides solution to the lapses of the 2D CAD technologies by ensuring a cooperative platform that brings together all building information in a single file, which can be exchanged and used by all the parties to a project (Abdulahi and Ibrahim, 2016). Several researchers have stated that the concept of BIM is devoid of a specific definition. For instance, RICS (2012) reported that the concept of BIM has no accepted definition, as a result of its evolving nature.

Kamadeen (2010) described the collaboration of all the features of BIM presented so far as a problem solving evolution that allows designers to easily optimize designs with analyses, simulations and visualizations which delivers a higher quality construction documentation. The prominent IT based information system, promotes and integrates the designs, assembles all operations of the building. The emergence of BIM is a turning point for the built environment, overcoming the barriers faced by all professionals. BIM presents a holistic view of a project from inception to completion even before it is actualized, thereby enabling remedial action to be taken for any identified risk.

\section{BIM based detailed cost estimating software}

BIM is not a software as described by various researchers but there is a software that is BIM based that helps integrate project data into a single file. BIM based estimating is described as a programmed progression that involves adapting data, exporting, and linking data with their respective unit cost. This process is different from the conventional approach to estimating (Ashworth, 2010). The manual process of carrying out these activities ranges from taking off up to preparation of draft bill of quantities. The integration of activities by BIM-enabled estimating helps in narrowing the operations of detailed estimating, thereby reducing the toilsome operations carried out in the manual method (Ashworth, 2010). However, many researchers have suggested that BIM enabled detailed estimating requires adequate knowledge and skills that are different from the traditional method. BIM based detailed cost estimating provides supplementary solution to the traditional and 2D CAD method. The unique feature of BIM based detailed cost estimating over traditional approach to estimating is the automation process. The capability of BIM based detailed cost estimating is its ability to automate the quantification process thereby overruling the enormous process in traditional estimating approach leaving ample time for the estimator to review and use his experience on the estimates generated. 
The use of detailed cost estimating does not automatically produce an estimate since estimates are not a function of the quantities generated automatically.Autodesk (2007) and Eastman et al. (2011) identified three approaches to carrying out BIM for detailed cost estimating software as follows:

- Exportation of quantities generated to estimating software: In this context, quantities are produced in the 3D BIM extracted into estimating software (spreadsheet) where unit rates are built and inserted to generate an estimate. Moses and Hampton (2017) stated that importing quantities from a BIM environment to estimating software involves selecting elements as a group or individually. The limitation of this approach is that there is no single database as to the applications used, which cannot link directly to BIM software. Examples of such applications include MS excel. For instance, Eastman et al. (2011) found that most BIM based estimating softwareis capable of exporting thequantities to a spreadsheet, thus enables the quantity surveyors to start the pricing. The quantity surveyors consider quantities that have been exported to MS Excel format assufficient for their work in BIM (Eastman et al., 2011). Similarly, Hardin (2009) claimed that it is inefficient to export the quantities if the BIM model and the spreadsheet are not linked in a way that the latter is automatically updated with the changesto the former.

- Linking BIM based software to estimating software: This entails the use of BIM estimating software directly linking to the BIM software. Eastman et al. (2011) stated that Tocomanilink estimating software can be plugged directly into design based software such as Revit. The plug-ins automatically generates quantities and the design tools aids visualization relating it with the estimate. Other examples of this softwareare Innovaya, Timberline etc. This approach also allows any quantities not generated automatically to be seen and imputed manually.

- Quantity take-off approach: This involves the use of quantity take off features that import data from the model depending on the level of the information provided by the model and also allows manual amendments to be made to the take-offs to the users' preference. Jiang (2011) stated that QTO processes can be finished automatically and categorized based on the information level on the object model, after the QTO changes can also be made manually. Examples of this software are Autodesk QTO, Exactal QTO, Vico among others.

The BIM based detailed cost estimating software identified in previous studies are summarized in Table I.

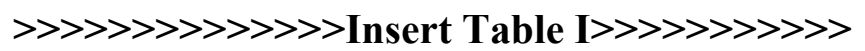

As indicated in Table I, BIM based cost estimating software varies in their functionality and working processes. For instance, the choice of BIM based detailed cost estimating software to be used depends on the needs of the user, availability in the market, the configuration, availability of experts, complexity, amongst many others. It is important to present an overview of how different BIM based estimating software can facilitate quantity surveyors' detailed cost estimating process. Therefore, few of the identified BIM based cost estimating software (see Table I) are briefly discussed as follows: 
Navisworks: This is a BIM based detailed cost estimating software developed by Autodesk for the review of project and administration for professionals and stakeholders in Architectural, engineering and construction (AEC). According to Finances online (2019), there are two versions of Navisworks: Navisworks manage and Navisworks simulation. The Navisworks manage has more sophisticated coordination, clash detection, 5D analysis and simulation while the Navisworks simulate specifies on reviewing and disseminates project information through the 5D analysis and simulation. The features of Navisworks to detailed cost estimating include: clash detection, quantification, coordination of data, model simulation and analysis, model review, project viewing, IFC file reader among many others (Finances online, 2019). In addition, it presents a lot of benefits which are reduction in cost; the Navisworks clash detection feature helps to streamline work flows which in turn help to reduce overspending and also saves time. Another benefit of this software is coordinated data; this software helps to integrate project data into a single model file which in turn saves time. It detects clashes which reduce the time that would have been taken to carry out this task manually.

Innovaya Composer: Innovaya composer is an auxiliary tool designed for Autodesk Revit and AutoCAD for architecture, mechanical, electrical, and plumbing (MEP). According to Innovaya (2011) Innovaya composer is designed to exploit the intelligent objects in the building information environment. This invention has changed the way professionals in the built environment carry out their duties and alongside enhance the communication between the team, planning, project estimating and quantity take off. Innovaya Composer imports data from Revit and exports the model into an INV file which can be read by Innovaya applications such as Innovaya Estimating and Innovaya Quantity Take off. The features of Innovaya composer include; automatic quantity generation, drag and drop quantity generation, coordinated object quantities, intelligent change management, quantity report to MS Excel, interactive 3D visualization, support for effective team communication, automatic quantity extraction, item take off.

BIM measure: This software is a product of the Causeway Computer Aided Take-Off (CATO) suite. It is an advancement of the CAD measure which has additional capabilities to visualize 3D models and utilize the data available in BIM mode for quantification. The features of this software are such that it enables users integrate various models and files into a single file and also the incorporation of BIM measure with other packages in the CATO suite enables cost to be managed effectively for BIM based project (Wu et al., 2014). BIM measure is compatible with various file formats such as DWFx, DWF, IFC, and PDF. Usually, files from Autodesk Revit are required to be transferred and converted into any of the aforementioned file format before they can work with the software. Wu et al. (2014) asserted that the beneficial features of BIM measure are visualization as it can easily be adjusted to users' convenient view, quantification although it does not automatically take off as the form of quantification needs to be defined during the process, but it has a user-friendly interface and easy to comprehend. The quantities produced by BIM measure are usually reliable as it gives the opportunity to use alternative model vetting tools alongside the software to ascertain the standard of BIM models before use.It also entails an in built classification for standard estimating in the CATO suite, the software also has report generating and data transfer features which allow the exportation of data to external spread sheets such as MS Excel or CATO suite provided, and lastly the inclusion of change management tool available in the CATO suite. 
Solibri Model Checker 8: Solibri Model Checker (SMC) software helps the BIM check for integrity, quality, and physical security. This software works similarly to an "X-ray". It scans the model to expose possible deficiencies and weakness of the design, identifying the items clashing and that there is compliance between the model, building codes and organization standards. It introduces an approach that is reliable and time saving compared to the traditional method of comparing files. According to Khelami (2011), the aforementioned attributes were the initial packages of the software. The author further stated that the interface of the software was improved and stretched to incorporate the take-off features which birthed the version 8 of the software.Wu et al. (2014) stated that the SMC 8 reads commendably the whole information on the IFC model, classifies components into a symbolic tree section, and updates them. SMC 8 is usually compatible with IFC, DWG or SMC files. The features of SMC 8 include visualization i.e. it displays the 3D design in the model and the model tree reveals information about an object and gives control of the view, the quantification feature uses the take -off feature which depends on the classification and definition to choose the type of information to be extracted on the model; builds structure and coordinates the data within the model. This software is flexible to use as it be adjusted to suit the users' convenient position. The information produced is reliable, availability of standard format for estimating, change management and report control.

Cost $X$ : This software allows the takeoff and view of 3D models (Exactal, 2010). CostX is a cost estimating software produced by an Australian developer in 2004 (Wu et al., 2014). It allows the inclusion and transference of data from BIM such data include: properties of object, descriptions measurement, and integrate them into a single file which comprises the spreadsheet measurements, estimates and measurements done electronically (Day, 2008). A unique feature of CostX is the model exchange, which is compatible with virtually all design formats such as Revit, DWFx, DWF IFC, JPEG, BMP, JPG and also 2D drawing formats such as PDF and DWG. The features of CostX includes: visualization, for this software the visualization is related to that of Revit (3D BIM). Another feature is the quantification process; this software allows this process to either be done manually or automatically and also the user can decide to work on the whole or part of the model. It allows the use of external devices i.e. plug in to extract the quantities generated from the BIM model. Reliability of information produced by the software, coordination of changes to BIM models, availability of standard classifications for estimating and report generation are essentials features of CostX software.

\section{Drivers to the adoption of BIM in quantity surveying practices}

Globally, BIM is increasingly becoming well known, and the clients are expecting quantity surveyors to adopt BIM in order to achieve accurate cost estimating, effective cost monitoring and control that are essential elements to construction projects success. Sattineni and Harrison (2014) claimed that BIM is largely used in construction projects compared to the use of BIM for detailed cost estimating, which have received low implementations. Therefore, the drivers for BIM adoption in quantity surveying practices identified from previous studies are presented in Table II as follows: 
As shown in Table II, the relative importance of the identified drivers was gauged from both the BIM users and non- BIM users' quantity surveying consulting firms in Nigeria. It is believed that this study would provide an in-depth understanding to the adoption of BIM in quantity surveying practices at large.

\section{Research methodology}

Since cost estimating is a core duty of quantity surveyors, the target population for this study comprised both the BIM users and non-BIM users' quantity surveying consulting firms in Lagos, Nigeria. The choice of the study area is due to the fact that a large percentage of quantity surveying consulting firms is situated in Lagos state. Thus, the study area is adjudged appropriate to conduct the survey to obtain required data (Babatunde, 2015). The study adopted literature review, pilot study, and questionnaire survey. For instance, the pilot study was conducted to identify the BIM users among the quantity surveying consulting firms in the study area. The outcome of pilot study revealed that 13 quantity surveying consulting firms are already using BIM (i.e. BIM users) in the study area and 124 quantity surveying consulting firms have not been using BIM (i.e. non-BIM users). The total list of quantity surveying consulting firms in the study area was obtained from the Nigerian Institute of Quantity Surveying (NIQS) directory of 2016. In order to capture broad perceptions of the respondents comprised BIM users and nonBIM users' quantity surveying consulting firms, this study adopted questionnaire survey. This approach is supported by Olatunji and Sher (2015) that quantitative approach is most used to explore estimating practice problems in construction management research. This approach is similar to earlier researchers on BIM studies. For instance, Kori and Kiviniemi (2015) used questionnaire when investigating BIM awareness in architectural firms. Ikediashi and Joseph (2016) adopted questionnaire to assess BIM for facility management roles.Hong et al. (2019) used questionnaire survey when exploring the BIM adoption for small and medium construction organizations in Australia. Chan et al. (2019) utilized questionnaire survey when assessing critical success factors for BIM implementation in Hong Kong. Babatunde and Ekundayo (2019) adopted questionnaire survey when investigating the barriers to the incorporation of BIM into quantity surveying undergraduate curriculum in the Nigerian universities. Oyewole and Dada (2019) used questionnaire survey to examine the training gaps in the adoption of BIM by Nigerian construction professionals, among others.

In the context of this study, both the non-probability and probability sampling techniques were employed. For example, the non-probability sampling technique adopted was purposive sampling technique, which was used to select BIM users among the quantity surveying firms. Also, for the non-BIM users, probability sampling technique precisely systematic random sampling was employed based on every $5^{\text {th }}$ firm on the list of registered firms after the exclusion of the BIM users. Thus, 13 BIM users and 24 non-BIM users'quantity surveying firms were selected, resulting into 37 quantity surveying firms. In order to have a wider perception, three copies of the questionnaire were distributed to each quantity surveying firm. This approach is supported by earlier studies in construction economics research (see Famakin et al., 2012; Badu et al., 2012; Babatunde and Perera, 2017) among others. In total, 111 (i.e. 37 x 3) copies of the questionnaire were self-administered to the BIM users and non- BIM users' quantity surveying firms in the study area. A total of 73 questionnaires comprised 31 BIM users and 42 non-BIM users were completed and suitable for the analysis. The data obtained were analyzed using both descriptive and inferential statistics through the Statistical Package for Social Science (SPSS V 21.0). These include mean score, standard deviation, Mann-Whitney test, and factor analysis. For 
instance, the Mann-Whitney test was undertaken to determine whether there is a statistically significant difference in the ranking of 21 identified drivers to the adoption of BIM based detailed cost estimating between the BIM users and non- BIM users' quantity surveying consulting firms.

\section{Results and discussions}

Background information of the respondents

Table III shows the background information of the respondents. This comprises respondents' years of experience, current designation, and highest level of academic qualification. This information helps to ensure that the characteristics of the respondents are identified as this contributes greatly to the reliability of this study. The respondents' years of experience revealed that $42.47 \%$ of the respondents have between 1 to 5 years of experience while $36.99 \%$ have between 6 to 10 years of experience and $20.55 \%$ have between 10 to 20 years of experience. The current designation of the respondents in their various quantity surveying consulting firms showed that $20.55 \%$ of the respondents are trainee quantity surveyors, $41.10 \%$ are assistant quantity surveyors, $12.33 \%$ are senior quantity surveyors, and $26.03 \%$ are chartered quantity surveyors. The highest academic qualification of the respondents indicated that majority of the respondents have Bachelor's degree representing $60.27 \%$ of the total respondent, followed by master's degree with $34.25 \%$ (see Table III for details).

>>>>>>>>>>>>>> Insert TableIII $>>>>>>>>>>>$

\section{Awareness and adoption of BIM based detailed cost estimating software}

This part of the study seeks to identify and examine the BIM based detailed cost estimating software being used in quantity surveying consulting firms. It started with the categorization of the respondents based on their knowledge of BIM and its application in detailed cost estimating. The results revealed that quite a number of the respondents are aware of BIM based detailed cost estimating and this indicates that the level of awareness has increased substantially among quantity surveying consulting firms. For instance, $46.58 \%$ of the respondents are aware of BIM and have adopted BIM for the detailed cost estimating, while $49.32 \%$ are aware but have not adopted BIM for detailed cost estimating. On the other hand, a small percentage of $4.10 \%$ of the respondents are not aware at all as shown in Figure I.

>>>>>>>>>>>>>> Insert Figure I $>>>>>>>>>>>$

Figure II shows the analysis of the BIM based detailed cost estimating software being used in quantity surveying consulting firms with the highest ranking of software being Microsoft excel used alongside 3D software with a frequency of 27 representing $69.23 \%$, followed by Autodesk QTO with a frequency of 24 accounting for $61.54 \%$. Navisworks was also identified by the respondents as one of the prominent BIM based detailed cost estimating software being used. The least software identified are Cost OSTM and Solibri Model checker with $2.56 \%$ (see Figure II for details). These study findings confirmed the assertion of Eastman et al. (2011) that quantity surveyors consider quantities that have been exported to MS Excel format as sufficient for their work in BIM. Similarly, Hardin (2009) claimed that it is inefficient to export the quantities if the 
BIM model and the spreadsheet are not linked in a way that the latter is automatically updated with the changes to the former.

\section{>>>>>>>>>>>>>> Insert Figure II $>>>>>>>>>>>$}

Ranking of the drivers to the adoption of BIM in quantity surveying practices

Table IV displays the ranking of the 21 identified drivers to the adoption of BIM in quantity surveying practices from the two groups comprised the BIM users and non-BIM users quantity surveying consulting firms. The results from BIM users revealed the values of mean score range from 3.47 to 4.72 . It can be deduced that 19 (out of 21) identified drivers have mean score values greater than 4.00. Similarly, the ranking from non-BIM users indicated that the values of mean score range from 3.80 to 4.71 . It can be seen that 17 (out of 21) identified drivers have mean score values greater than 4.00. These findings are not surprising as it only indicates that the respondents from the two groups are fully aware of the drivers to the adoption of BIM based detailed cost estimating. Furthermore, as shown in Table IV, the results produced from the mean ranking from both the BIM users and non- BIM users agreed that the 21 identified drivers are important drivers to the adoption of BIM based detailed cost estimating. This is supported by earlier studies, for instance, Badu et al.(2012) stated that a factor is important if it has a mean score value of 3.5 or above based on a five point Likert scale. In addition, the top five total mean ranking from both BIM users and non-BIM users are as follows: automation of quantities; time saving in the preparation of quantities; enhanced quality of decision; data coordination; and streamlining design activities and improving design quality, respectively. These study findings confirm the existing literature. For instance, Gier (2007) asserted that reduction in the length of time needed by quantity surveyors to come up with a detailed estimate and improvement in the quality of estimates in terms of accuracy are drivers of BIM based detailed estimating. Olatunji and Sher (2010) stated that BIM provides solution to the traditional method of carrying out estimating task that are voluminous, prone to errors, omissions and ethical faults.

The Mann-Whitney test was undertaken to test if there was any significant difference in the perceptions of the two groups (i.e. BIM users and non-BIM users). The significant level is 5 percent (0.05). As shown in Table IV, the p-values produced from the Mann Whitney test are above 0.05 , thereby signifying that there is no significant difference between the perceptions of the two groups in the mean ranking of the drivers to the adoption of BIM. It can be concluded that the respondents are aware of the drivers to the adoption of BIM in quantity surveying practices.

\section{>>>>>>>>> Insert Table IV $>>>>>>>>>>$}

\section{Factor analysis of the drivers to the adoption of BIM in quantity surveying practices}

Factor analysis was conducted in this study; using principal factor extraction with varimax rotation on 21 identified drivers to the adoption of BIM in quantity surveying practices. Factor analysis was carried out to identify the major relationships among the 21 identified drivers and determine the underpinning interactions or grouping that might exist between the identified drivers. Using factor analysis is supported by earlier BIM studies. For instance, Oduyemi et al. (2017) used factor analysis when studying the application of BIM in sustainable building design. Amuda-Yusuf (2018) conducted factor analysis when assessing the critical success factors for BIM implementation among others. Prior to the carrying out of factor analysis, Kaiser-Mayer- 
Olkin (KMO) and Barlett's test of sphericity were conducted to confirm the data obtained are suitable for factor analysis. For instance, Kaiser (1974) stated that a KMO value less than 0.60 is not appropriate for factor analysis. As indicated in Table V, the result of KMO value is 0.849 , which indicates that the data obtained is appropriate for factor analysis. Also, Bartlett's test of sphericity is 0.000 , which signifies a strong correlation. This is supported by earlier studies that sphericity test should be less than 0.05 (Field, 2005; Pallant, 2007). It is obvious that the data obtained is appropriate for factor analysis given that the results of the KMO and sphericity are satisfactory.

\section{>>>>>>>> Insert Table $V>>>>>>>>>>$}

Table VI shows the factor analysis undertaken on the 21 identified drivers to the adoption of BIM in quantity surveying practices. Principal component analysis (PCA) and eigenvalues were employed when conducting the factor analysis. This approach is widely supported by earlier studies. For instance, Pallant (2010) and K'Akumuet al. (2013) stated that eigenvalues are vital in factor analysis as a decision making criterion and the eigenvalue that greater than 1.0 should be used for further investigation. As indicated Table VI, five factors with their eigenvalues ranging from 1.334 to 5.961 , including the total variance of $28.388 \%$ for the first factor, and $6.353 \%$ for the fifth factor. Also, the cumulative percentage of the total variance of the five factors amounts to $73.325 \%$ (see Table VI for details). Also, the factor loadings of the extracted factors ranging from 0.329 to 0.809 , this implied that all factors are important and none of the variables needs to be eliminated (see Kline, 2002; Brown, 2009).

\section{>>>>>>>>> Insert Table $V I>>>>>>>>>>$}

The extracted five factors are interpreted as follows:

Factor 1: Improved whole life cycle and improved design quality

Factor 2: Enhanced decision and visualization

Factor 3: Cost and time saving in preparation of detailed cost estimating

Factor 4: Marketing and support for quantity surveyors' tasks

Factor 5: Government and client pressure

\section{Factor 1: Improved whole life cycle and improved design quality}

This factor amounts to $28.388 \%$ of the total variance of the drivers to the adoption of BIM in quantity surveying practices (see Table VI). The components include improving the capacity to provide whole life value to client; improving design quality; increased efficiency in monitoring; precise future prediction of construction costs; accurate construction sequencing and clash detection; desire for innovation to remain competitive; increase profitability; reliability of estimate; client and competitive pressure, reduces variability in cost estimate; and collaborative working and communication between stakeholders. These 11 components have factor loadings ranging from 0.809 to 0.415 (see Table VI for details). This finding affirmed previous studies that alluded to the fact that BIM implementation will significantly augment traditional role of quantity surveyors, and these roles through BIM are achieved more efficiently (Ashworth and Hogg, 2007; Pittard, 2012). For instance, Wong et al. (2014) identified the benefits of BIM as easily generated accurate cost estimates for various design alternatives or options. Monteiro and Martins (2013) stated that BIM provides detailed and accurate estimate for construction projects. 


\section{Factor 2: Enhanced decisions and visualization}

This factor amounts to $13.870 \%$ of the total variance of the drivers to the adoption of BIM in quantity surveying practices. The main components include: enhanced quality of decisions; visualization; data coordination; and automation of quantities. The four components have factor loadings: $0.831 ; 0.746 ; 0.698$; and 0.503 , respectively (see Table VI). This finding confirmed the existing literature. For instance, Aliet al. (2014) claimed that BIM offers solution to the problem associated with the traditional method and 2D CAD. For example, inadequate interpretation of drawings as led to many assumptions that have resulted into errors in detailed cost estimating. Hence, visualization is a drive to the adoption of BIM for detailed cost estimating. This is corroborated by Sunil et al. (2015) that the benefit of BIM in detailed cost estimating is visualization, as it helps in better comprehension of the design and features of the buildings. Also, the model visualization attributes provided by the BIM is an essential tool that will improve quantity surveyors decision making. Therefore, BIM support for improved decision making is an essential driver for its adoption in detailed cost estimating by professional quantity surveyors.

\section{Factor 3: Cost and time saving in preparation of detailed cost estimating}

This factor has $13.506 \%$ of the total variance of the drivers to the adoption of BIM in quantity surveying practices. This factor has two major components to include: cost saving in the preparation of detailed estimating; and time saving in the preparation of detailed cost estimating with their factor loadings of 0.848 , and 0.679 respectively. This finding confirms the earlier studies. For instance, Gier (2007) found out that reduction in the length of time needed by quantity surveyors to come up with a detailed estimate and improvement in the quality of estimates in terms of accuracy are benefits of BIM based detailed estimating. This is affirmed by Olatunji and Sher (2010) that BIM provides solution to the traditional method of carrying out estimating tasks, which are voluminous, prone to errors, and omissions. The use of BIM for detailed cost estimating will enable the quantity surveyors to give faster cost feedback on matters related to cost on the construction projects. This improvement in the quantity surveyor's role is evident as important driver for BIM based detailed cost estimating. This is corroborated by Matipa (2005) who stated that the adoption of BIM, particularly for detailed cost estimating would allow the quantity surveyors to have more time for cost information; thereby enables quantity surveyors to provide faster cost feedback on matters related to cost on construction projects.

\section{Factor 4: Support for quantity surveyors' tasks and marketing purpose}

This factor amounts to $11.208 \%$ of the total variance of the drivers to the adoption of BIM in quantity surveying practices. This factor has two main components to include: support for quantity surveyor task; and marketing purpose with factor loadings of 0.755 and 0.554 , respectively (see Table VI).This finding found that at peak times the quantity surveyor can be involved in so many projects which are to be delivered almost at the same time or within limited intervals.BIM automation and its feature at large is a tool that will assist quantity surveyors in carrying out estimating task, and produce accurate cost estimate. Also, the need to improve the marketing level of quantity surveyors is further a drive to BIM implementation (Olatunji et al., 2010). Therefore, quantity surveyors can adopt BIM as a strategy for marketing. 
Factor 5: Government and client pressure

This factor amounts to $6.353 \%$ of the total variance of the drivers to the adoption of BIM in quantity surveying practices. The main component is government pressure towards better practices with a factor loading of 0.838 (see Table VI). This finding is affirming the earlier studies that identified government pressure as a driver to BIM adoption in the construction industry. For example, governments of both the UK and Australia have made the use of BIM in public sector projects compulsory since the year 2016 (Efficiency and Reform Group, 2011; buildingSMART Australasia, 2012). Also, external forces, particularly from the clients play a vital role in the adoption of BIM (Liu et al., 2010).

\section{Conclusion}

As a trend to obtain global competitiveness, quantity surveyors should position themselves readily to adopt new innovations. BIM has presented numerous benefits to the quantity surveying activities at large and most especially detailed cost estimating that requires enormous time to achieve its processes.This study identified and examined the BIM based detailed cost estimating software; and assessed the drivers to the adoption of BIM among quantity surveying consulting firms. The findings of this study revealed that $46.58 \%$ of quantity surveying consulting firms are aware of BIM and have adopted it for detailed cost estimating, while $49.32 \%$ are aware of BIM but have not adopted BIM for detailed cost estimating, and $4.10 \%$ of quantity surveying consulting firms is not aware at all. These findings show an increase in the percentage of BIM awareness and its usage in quantity surveying consulting practices compared to previous studies. This is very encouraging, and it could be attributable to the professional bodies such as the RICS sensitization on the importance of BIM to quantity surveying practices.

Also, the study identified various BIM based detailed cost estimating software used in quantity surveying consulting practices and found that Microsoft excel being used alongside 3D software, Autodesk QTO, Navisworks, Innovaya composer, and CostX respectively are prevalent BIM software used for detailed cost estimating. In addition, the study identified 21 drivers to the adoption of BIM in quantity surveying practices. The relative importance of these 21 drivers were gauged from the two groups comprised the BIM users and non-BIM users quantity surveying consulting firms. The results from BIM users revealed that 19 (out of 21) identified drivers have mean score values greater than 4.00. While the results from non-BIM users indicated that 17 (out of 21) identified drivers have mean score values greater than 4.00. These findings are not surprising as they only pointed to the fact that both the BIM users and non-BIM users' quantity surveying consulting firms are fully aware of the drivers for the adoption of BIM based detailed cost estimating. In addition, the top five overall ranked drivers from both BIM users and non-BIM users are as follows: automation of quantities; time saving in the preparation of quantities; enhanced quality of decision; data coordination; and improving design quality, respectively. Furthermore, the results of Mann-Whitney test indicated that there is no statistically significant difference between the perceptions of BIM users and non-BIM users in the mean ranking of identified 21 drivers to the adoption of BIM in quantity surveying practices.Moreover, the result of factor analysis grouped the 21 identified drivers into five principal factors to include: improved whole lifecycle/design quality; enhanced decision and visualization; cost and time saving; support for quantity surveyors' tasks and marketing purpose; and government and client pressure. 
This study is not without limitation. Although using questionnaire survey allows large sample to be captured, having other methods together such as interviews may enrich the findings. Despite this limitation, this study provides valuable insight into the application of BIM to quantity surveying consulting practices; thereby enabling consultant quantity surveyors to make informed decisions to select appropriate BIM cost estimating software to suit their practices. Further, the findings of this study can be useful for individuals, clients' and contractors' quantity surveyors by making them have awareness on the opportunities BIM could bring in relation to their service delivery. Since, accurate cost estimating, effective cost monitoring and control are essential elements to construction projects success. This study further emphasized the importance of BIM to quantity surveying practices at large, particularly the detailed cost estimating. This study was limited to quantity surveying consulting firms. Therefore, further study should be conducted to capture both clients' and contractors' quantity surveyors' perspectives in both developing and developed countries at large.

\section{References}

Abdullahi, M. and Ibrahim, Y.M. (2016), "Building information modeling, paper presented at 3-Day Workshop/Annual General Meeting of the Nigerian Institute of Quantity Surveyors, available at: http://niqs.org.ng/wp-content/uploads/2016/ (accessed 20 August 2018).

Ali, K.N., Mustaffa, N.E., Keat, Q.J. and Enegbuma, W.I. (2015), "Building information modeling educational framework for quantity surveying students: the Malaysian perspective", Journal of Information Technology in Construction (ITcon), Vol. 21, pp. $140-151$.

Alufohai, A. (2012), “Adoption of building information modeling and Nigeria's quest for project cost management", Journal ofNigerian institute of quantity surveyors, Vol.1 No.1, pp.610.

Amuda-Yusuf, G. (2018), "Critical success factors for building information modeling implementation", Construction Economics and Building,Vol.18 No.3, pp.55-73.

Ashworth, A. and Hogg, K. (2007), Willis's Practice and Procedure for the Quantity Surveyor, BlackwellPublishing Ltd, Oxford.

Ashworth, A. (2010), Cost Studies of Building, 5th ed., Pearson Prentice Hall, Harlow.

Autodesk (2007), BIM and Cost estimating, available at: http://www.consortech.com/bim2/documents/BIM cost_estimating_EN.pdf (accessed 10 April 2019).

Azhar, S. (2011), "Building information modeling (BIM): trends, benefits, risks, and challenges for the AEC industry", Leadership and Management in Engineering, Vol. 11 No. 3, pp. 241-252.

Babatunde, S.O. (2015), "Developing public private partnership strategy for infrastructure delivery in Nigeria", Doctoral thesis, Northumbria University, UK. 
Babatunde, S.O. and Perera, S. (2017), "Barriers to bond financing for public-private partnership infrastructure projects in emerging markets: a case of Nigeria", Journal of Financial Management of Property and Construction, Vol. 22 No.1, pp.2-19.

Babatunde, S.O., Ekundayo, D., Babalola, O. and Jimoh, J. A. (2018), "Analysis of the drivers and benefits of BIM incorporation into quantity surveying profession: Academia and students' perspectives",Journal of Engineering, Design and Technology, Vol.16 No.5, 750-766.

Babatunde, S.O. and Ekundayo, D. (2019), "Barriers to the incorporation of BIM into quantity surveying undergraduate curriculum in the Nigerian universities", Journal of Engineering, Design and Technology, Vol. 17 No.3, pp. 629-648.

Badu, E., Edwards, D.J., Owusu-Manu, D. and Brown, D.M. (2012), "Barriers to the implementation of innovative financing (IF) of infrastructure", Journal of Financial Management of Property and Construction, Vol. 17 No. 3, pp. 253-273.

Boon, J. (2009), Preparing for the BIM revolution, in 13th Pacific Association of Quantity Surveyors Congress (PAQS 2009), The Institution of Surveyors Malaysia, Malaysia, pp $33-40$.

Brown, J. D. (2009), "Choosing the right type of rotation in PCA and EFA," JALT Testing and Evaluation SIG Newsletter, Vol.13 No.3, pp.20-25.

buildingSMART Australasia (2012), "National building information modeling initiative report", available at: www.innovation.gov.au/Industry/BuildingandConstruction/BEIIC/Documents/NBIMIRe port.pdf(accessed 22 April 2019).

Chan,D.W.M., Olawumi, T.O. and Ho, A.M.L (2019), "Critical success factors for building information modeling implementation in Hong Kong”, Engineering, Construction and Architectural Management (In Press).

Cheunga, F., Rihana, J., Taha, J., Duceb, D. and Kurula, E. (2012), "Early stage multi-level cost estimation for schematic BIM models", Automation in Construction, Vol. 27, pp. 67-77.

Dare-Abel, O. A., Igwe, J. M. and Charles, K. A. (2014), "Proficiency and capacity building of human capital in architectural firms in Nigeria", International Conference on Science, Technology, Education, Arts, Management \& Social Sciences, iSTEAMS Research Nexus Conference, AfeBabalola University, Ado-Ekiti, Nigeria, May, 2014.

Day, M. (2008), Exactal CostX, available at: fromhttp://aecmag.com/index.php?option=com_content\&task=view\&id=249\&Itemid=32 (accessed 10 April 2019).

Eadie, R., Odeyinka, H., Browne, M., Mckeown, C. and Yohanis, M. (2013),“An analysis of the drivers for adopting building information modelling", Journal of Information Technology in Construction, Vol.18,pp.338-352.

Eastman, C., Teicholz, P., Sacks, R. and Liston, K. (2011), BIM Handbook: A Guide to Building Information Modeling, John Wiley \& Sons, New Jersey.

Efficiency and ReformGroup (ERG) (2011), Government Construction Strategy, Cabinet Office, London. 
Exactal (2010), CostX Whitepaper, available at: http://www.exactal.co.uk/sites/default/files/pdf/CostX-White-Paper v3.20.pdf (accessed 10 April 2019).

Famakin, I.O., Aje, I.O. and Ogunsemi, D.R. (2012), "Assessment of success factors for joint venture construction projects in Nigeria", Journal of Financial Management of Property and Construction, Vol. 17 No. 2, pp. 153-165.

Field, A. (2005), Discovering Statistics using SPSS, Sage, London.

Finances Online (2019), Product review: Navisworks, available at:https://reviews.financeonline.com/p/navisworks (accessed 9 August 2019).

Frei, M., Mbachu, J. and Phipps, R. (2013), "Critical success factors, opportunities and threats of the cost management profession: the case of Australasian quantity surveying firms", International Journal of Project Organization and Management, Vol. 5 No. 1, pp.4-24.

Gier, D. M. (2007), What impact does using building information modeling have on teaching estimating to construction management students?, available at:http://ascpro0.ascweb.org/archives/cd/2008/paper/CEUE179002008.pdf(accessed 22 April 2019).

Hardin, B. (2009). BIM and Construction Management: Proven Tools, Methods, and Workflows, Wiley Publishing Inc., Indianapolis.

Hong, Y., Hammad, A.W.A., Sepasgozar, S. and Akbarnezhad, A. (2019), "BIM adoption model for small and medium construction organisations in Australia", Engineering, Construction and Architectural Management, Vol. 26 No. 2, pp. 154-183.

Ikediashi, D. and Joseph, U. (2016), "Adoption of BIM technologies for facilities management roles in Nigeria: an empirical investigation", Paper presented at the ICCREM.

Innovaya (2019), Product review: Innovaya composer, available at https://www.innovaya.com/prod-vq.htm (accessed 9 August 2019).

Ismail, A.A., Idris, H.N., Ramli, H., Sahamir, S.R.andRooshdi, M.R. (2018),"Sustainable BIMbased cost estimating for quantity surveyors", The Italian Association of Chemical Engineering.pp.235-236.

Jiang, X. (2011), Developments in cost estimating and scheduling in BIM technology, Northeastern University.

K'Akumu, O.A., Jones, B. and Yang, J. (2013), "Factor analysis of the market environment for artisanal dimension stone in Nairobi, Kenya", Journal of Construction in Developing Countries, Vol. 18 No. 2, pp. 15-32.

Khemlani, L. (2009) AECbytesproduct review: Solibri model checker,available at: AECbytes:http://www.aecbytes.com/review/2009/SolibriModelChecker.html(accessed 9 August 2019).

Khemlani, L. (2011) AECbytesproduct review: Solibri model checker v7, available at: http://www.aecbytes.com/review/2011/SolibriModelCheckerv7.html (accessed 9 August 2019).

Kline, P. (2002) An Easy Guide to Factor Analysis, Routledge, London. 
Kori, S. A. and Kiviniemi, A. (2015), "Toward adoption of BIM in the Nigerian AEC industry", Paper presented at the 9th BIM Academic Symposium \& Job Task Analysis Review.

Kulasekara, G., Jayasena, H.S. and Ranadewa, K.A.T.O. (2013), "Comparative effectiveness of quantitysurveying in a building information modeling implementation", Second World ConstructionSymposium 2013: Socio-Economic Sustainability in Construction, Colombo, June 14-15.

Liu, R., Issa, R. andOlbina. S. (2010), "Factors influencing the adoption of building information modeling in the AEC Industry",available at: http://www.engineering.nottingham.ac.uk/icccbe/proceedings/pdf/pf70.pdf (accessed 16 December 2018).

Luth, G.P., Schorer, A. and Turkan, Y. (2014), "Lessons from using BIM to increase designconstruction integration", Practice Periodical on Structural Design and Construction, Vol. 19 No. 1, pp. 103-110.

Matipa, W. M., Cunningham, P. and Naik, B. (2010), “Assessing the impact of new rules of cost planning on building information model (BIM) pertinent to quantity surveying practice",Proceedings of the $26^{\text {th }}$ ARCOM Conference, pp. 625-632.

Matipa, W. M., Kelliher, D. and Keane, M. (2005), “A strategic view of ICT supported cost management for green buildings in the quantity surveying practice", Journal of Financial Management of Property and Construction, Vol.14 No.1, pp. 79-89.

Mayouf, M., Gerges, M. and Cox, S. (2019), "5D BIM: an investigation into the integration of quantity surveyors within the BIM process", Journal of Engineering, Design and Technology, Vol. 17 No.3, pp. 537-553.

Monteiro, A.and Martins, J.P. (2013), "A survey on modeling guidelines for quantity takeoff oriented BIM-based design", Automation in Construction, Vol.35, pp.238-253.

Morledge, R. and Kings, S. (2006), "Bill of quantities - a time for change", proceedings of the International Conference in the Built Environment in the 21st Century (ICIBE 2006)" pp. UniversitiTeknologi Mara, Malaysia, pp.49-56.

Moses, T. and Hampton, G. (2017), Cost certainty: a lead driver for 5D building information modeling implementation, in 21st Pacific Association of Quantity Surveyors Congress (PAQS 2017), 24 ${ }^{\text {th }}$ 25 th July, 2017, Vancouver, BC, Canada, pp 30-53.

Nagalingam, G., Jayasena, H. S and Ranadewa, K. A. (2013), "Building information modelling and future quantity surveyor's practice in Sri Lankan construction industry", The Second World Construction Symposium, Socio-Economic Sustainability in Construction, , Colombo, Sri Lanka, pp.81-92.

Olatunji, O.A., Sher, W. and Gu, N. (2010), "Building information modelling and quantity surveying practice”, Emirates Journal for Engineering Research, Vol.15 No.1, pp.67-70.

Olatunji, O.A. and Sher, W. (2014), "Perspectives on modelling BIM-enabled estimating practices", Australasian Journal of Construction Economics and Building, Vol. 14 No. 4, pp. 32-53.

Olatunji, O. and Sher, W. (2015), "Estimating in geometric 3D CAD”, Journal of Financial Management of Property and Construction, Vol. 20 No.1, pp.24-49. 
Olawumi, T.O. and Chan, D.W.M. (2018), "Identifying and prioritizing the benefits of integrating BIM and sustainability practices in construction projects: a Delphi survey of international experts", Sustainable Cities and Society, Vol. 40, pp. 16-27.

Olugboyega, O. and Aina, O. (2016), "Analysis of building information modelling usage indices and facilitators in the Nigerian construction industry", Journal of Logistics, Information and Service Sciences. Vol.3 No.2, pp.1-36.

Oyewole, E.O. and Dada, J.O (2019),"Training gaps in the adoption of building information modeling by Nigerian construction professionals", Built Environment Project and Asset Management, Vol. 9 No.3, pp. 399-411.

Pallant, J. (2007) SPSS Survival Manual: A Step by Step Guide to Data Analysis using SPSS for Windows, Open University Press, Berkshire.

Pallant, J. (2010). SPSS Survival Manual: A Step to Step Guide to Data Analysis Using SPSS for Windows, Open University Press.

Pittard, S. (2012), What is BIM?, available at: http://fat.glam.ac.uk/media/files/documents/201203-16/What_is_BIM_1_.PDF(accessed 16 December 2018).

Rajith, D.B.A. (2016), Quantity Surveying Practice with the adoption of BIM application in Sri Lanka. BSc. dissertation, Sheffield University, UK.

Raphael, V. and Priyanka, J. (2014), "Role of building information modelling in quantity surveying practice",International Journal of Civil Engineering and Technology, Vol.5 No.12, pp.194-200.

Royal Institution of Chartered Surveyors (2012), Building Information Modeling Survey Report, available at: http://www.scan2bim.info/ files/rics_2011_BIM_Survey_Report.pdf (assessed 16 December 2018).

Sattineni, A. and Bradford, H. (2012), "Estimating with BIM: a survey of US construction companies", Proceedings of ISARC, Korea, Seoul, pp.564-569.

Shen, Z. and Issa, R. R. A. (2010), "Quantitative evaluation of the BIM-assisted construction detailed cost estimates",Journal of Information Technology in Construction (ITcon), Vol.15, pp.234-257.

Smith, P. (2016), "Project cost management with 5D BIM",Procedia - Social and Behavioral Sciences, Vol.226, pp.193-200.

Song, W. (2014), "A technical review of BIM based cost estimating in UK quantity surveying practice, standards and tools", Journal of Information Technology in Construction (ITcon), Vol.19 No.1, pp.534-563.

Stanley, R. and Thurnell, D (2014)," The benefits of, and barriers to, implementation of 5D BIM for quantity surveying in New Zealand", Australasian Journal of Construction Economics and Building, Vol.14 No.1, pp.105-117.

Succar, B.,Sher, W. and Williams, A. (2012), "Measuring BIM performance: five metrics",Journal of Architectural Engineering and Design Management, Vol.8 No.2, pp. $120-142$. 
Sunil, K., Pathirage, C. and Underwood, J. (2015), “The importance of integrating cost management with building information modeling",Paper presented at the 12th International Post-Graduate Research Conference, Salford, UK.

Thurairajah,N. and Goucher,D. (2013), "Advantages and challenges of using BIM: a cost consultant's perspective",ASC Annual International Conference Proceedings, California.

Thurairajah, N. and Goucher, D. (2012), "Usability and impact of BIM on early estimation practices: a cost consultant's perspective", Proceeding of International Congress on Construction Management Research, Montreal, Canada.

Tiwari, S., Odelson, J., Watt, A. and Khanzode, A. (2009), "Model based estimating to inform target value design", available at:http://www.aecbytes.com/buildingthefuture/2009/ModelBasedEstimating.html(accesse d 20 March 2019)

Wijayakumar, M. andJayasena, H. S. (2013), “Automation of BIM quantity take-off to suit QS's requirements", The Second World Construction Symposium 2013: Socio-Economic Sustainability in Construction, Colombo, Sri Lanka,pp.70-80.

Wong, K., Wong, K. and Nadeem, A. (2011), "Building information modelling for tertiary construction education in Hong Kong", Journal of Information Technology in Construction, Vol.16, pp.467-476.

Wong, P. F., Salleh, H. and Rahim, F. A. (2014), "Capability of building information modeling application in quantity surveying practice", Journal of Surveying, Construction and Property, Vol.5 No.1,pp.1-13.

Wong, P. F., Salleh, H. and Rahim, F. A. (2014),“The relationship of building information modeling capability in quantity surveying practice and project performance",International Journal of Civil, Environmental, Structural, Construction and Architectural Engineering, Vol.8 No.10, pp.1031-1036.

Wu, S., Wood, G., Ginige, K. and Jong, S.W. (2014), "A technical review of BIM based cost estimating in UK quantity surveying practice, standards and tools",Journal of InformationTechnology in Construction (ITcon), Vol. 19, pp. 534-563.

Yan, H. and Damian, P. (2008), Benefits and barriers of building information modeling, in 12th International Conference on Computing in Civil and Building Engineering, 16 ${ }^{\text {th }}$ $18^{\text {th }}$ October, 2008, Beijing, China. 


\section{List of Figures}

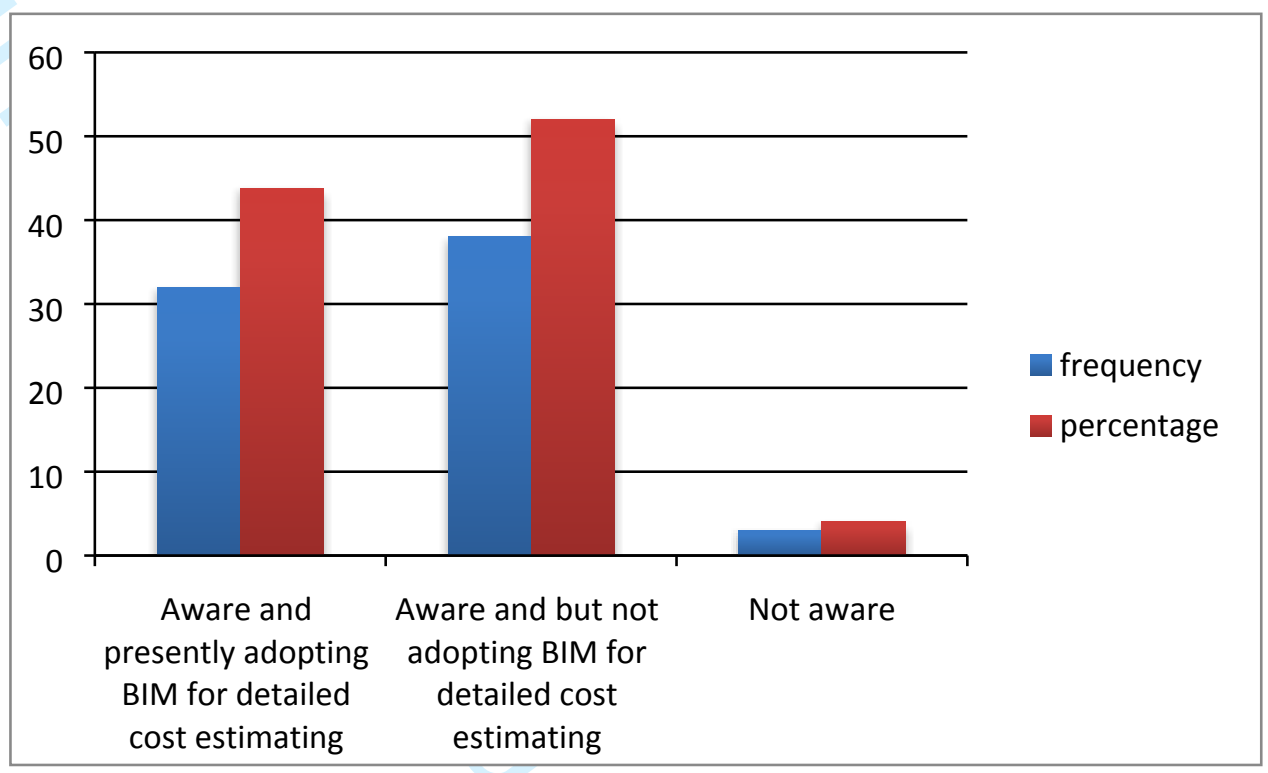

Figure I. Awareness and adoption of BIM based detailed cost estimating in quantity surveying consulting firms

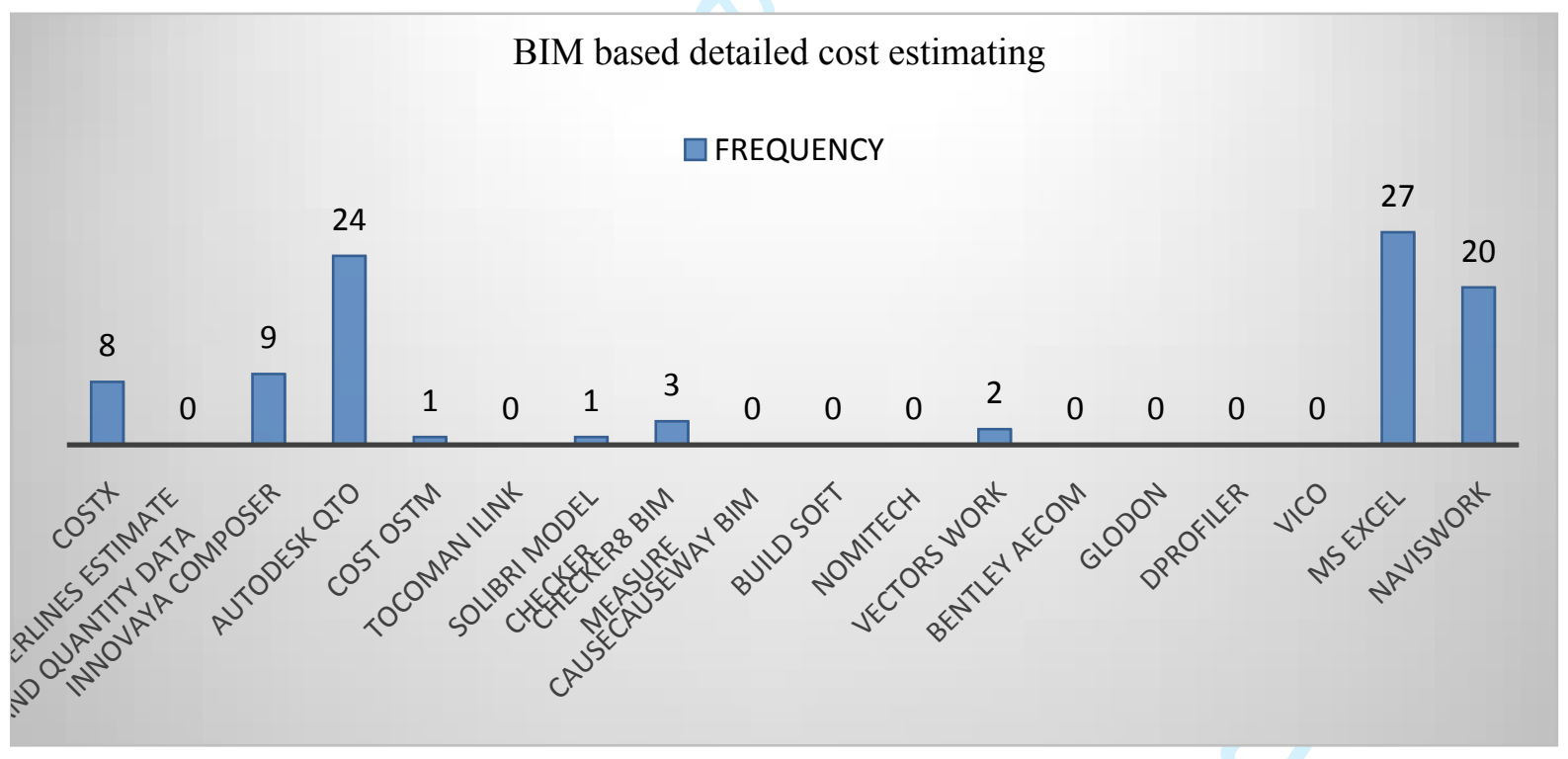

Figure II: BIM based detailed cost estimating software in use in quantity surveying consulting firms 


\section{List of Tables}

Table I: BIM based detailed cost estimating software

\begin{tabular}{|c|c|}
\hline BIM Software & Source \\
\hline CostX & $\begin{array}{l}\text { Smith, 2014; Wong et al., 2014; Moses and } \\
\text { Hampton, } 2017\end{array}$ \\
\hline Innovaya composer & Sattineni and Harrison, 2009. \\
\hline Timberline's estimate and quantity data & Smith, 2014; Zulkipli and Lim, 2015. \\
\hline Autodesk QTO & $\begin{array}{l}\text { Wu et al., 2014; Wong et al., 2014; } \\
\text { Kulesekara et al., } 2013\end{array}$ \\
\hline Tocoman ilink & Eastman et al., 2011. \\
\hline Vico office & $\begin{array}{l}\text { Wu et al., 2014; Zulkipli and Lim, 2015; } \\
\text { Moses and Hampton, } 2017 .\end{array}$ \\
\hline Solibri model checker & $\begin{array}{l}\text { Wong et al., 2014; Moses and Hampton, } \\
2017 .\end{array}$ \\
\hline Causeway BIM & $\begin{array}{l}\text { Wong et al., 2014; Moses and Hampton, } \\
2017 .\end{array}$ \\
\hline Build soft & Wong et al., 2014. \\
\hline Bentley & Moses and Hampton, 2017 \\
\hline Glodon & Zulkipli and Lim, 2015 \\
\hline Checker8 BIM measure 16.4 & Wong et al., 2014 \\
\hline CostOSTM & Moses and Hampton, 2017 \\
\hline Nomitech for BOQ preparation & Kulesekara et al., 2013 \\
\hline D profiler & Kulesekara et al., 2013 \\
\hline Vector works & Wong et al., 2014. \\
\hline
\end{tabular}


Table II: Drivers to the adoption of BIM based detailed cost estimating

\begin{tabular}{|c|c|}
\hline Drivers & Source \\
\hline Enhanced roles of quantity surveyor & Matipa et al., 2005; Matipa et al., 2010; Sunil et al., 2015 \\
\hline Improved quality of judgments & Gier, 2007; Sunil et al., 2015 \\
\hline Enhanced team work among professionals & Ismail et al., 2018. \\
\hline Backing for quantity surve & Gier, 2007; Olatunji and Sher, 2010; Sunil et al., 2015 \\
\hline Visualisation & Eadie et al., 2013; Ali et al., 2014; Sunil et al., 2015 \\
\hline Reliability of estimate & $\begin{array}{l}\text { Matipa et al., 2010; Shen and Issa, 2010; Monteiro and Martins, } \\
\text { 2013; Choi et al., 2015; Kim and Kim, 2015; Ismail et al., } 2016\end{array}$ \\
\hline Data coordination & Ismail et al., 2018 \\
\hline Marketing purpose & Olatunji, 2012 \\
\hline $\begin{array}{l}\text { Cost saving in preparation of detailed } \\
\text { estimate }\end{array}$ & Tiwari et al., 2009; Ismail et al., 2018 \\
\hline $\begin{array}{l}\text { Time saving in preparation of detailed } \\
\text { estimate }\end{array}$ & $\begin{array}{l}\text { Matipa et al., 2005; Gier, 2007; Tiwari et al., 2009; Sunil et al., } \\
\text { 2015; Ismail et al., } 2018\end{array}$ \\
\hline Increase profitability & Ismail et al., 2018 \\
\hline Automation of quantities & $\begin{array}{l}\text { Tiwari et al., 2009; Wu et al., 2014; Choi et al., 2015; Sunil et } \\
\text { al., 2015; Moses and Hampton, } 2017\end{array}$ \\
\hline
\end{tabular}

Government pressure towards better practices

Client and competitive pressure

Streamlining design activities and improving design quality

Desire for innovation to remain competitive

Improving the capacity to provide whole life value to client

Increased efficiency in monitoring with reduction of requests for information

Eadie et al., 2013

Liu et al., 2010; Lu and Li, 2011; Eadie et al., 2013

Eastman et al., 2011; Eadie et al., 2013

Moore, 2003; Eadie et al., 2013

Reduces variability in cost estimate

Azhar et al., 2011; Eadie et al., 2013

Eadie et al., 2013

Eadie et al., 2013; Choi et al., 2015 


\begin{tabular}{ll}
\hline \multicolumn{1}{c}{ Drivers } & Source \\
\hline $\begin{array}{l}\text { Accurate construction sequencing and } \\
\text { clash detection }\end{array}$ & Eadie et al., 2013 \\
$\begin{array}{l}\text { It allows precise future prediction of } \\
\text { construction costs }\end{array}$ & Eadie et al., 2013 \\
$\begin{array}{l}\text { Facilitating increased prefabrication with } \\
\text { information rich BIM }\end{array}$ & Eadie et al., 2013 \\
\hline
\end{tabular}

Table III: Background information of the respondents

\begin{tabular}{lccc}
\hline Background information & Frequency & Percentage & Cumulative \% \\
\hline Years of experience of the respondents & & & \\
1 to 5 years & 31 & 42.46 & 42.46 \\
6 to 10 years & 27 & 36.99 & 79.45 \\
10 to 20 years & 15 & 20.55 & 100.00 \\
Above 20 years & - & - & \\
Total & $\mathbf{7 3}$ & $\mathbf{1 0 0 . 0 0}$ & \\
Current designation of the respondents & & & \\
Trainee quantity surveyor & 15 & 20.55 & 20.55 \\
Assistant quantity surveyor & 30 & 41.10 & 61.65 \\
Senior quantity surveyor & 9 & 12.32 & 73.97 \\
Chartered quantity surveyor & 19 & 26.03 & 100.00 \\
Total & $\mathbf{7 3}$ & $\mathbf{1 0 0 . 0 0}$ & \\
Highest academic qualifications & & & \\
HND & 3 & 4.11 & 4.11 \\
BSc & 44 & 60.27 & 64.38 \\
MSc & 25 & 34.25 & 98.63 \\
PhD & 1 & 1.37 & 100.00 \\
Total & $\mathbf{7 3}$ & $\mathbf{1 0 0 . 0 0}$ & \\
Professional qualification of the respondents & & & \\
Probationer & 19 & 26.02 & 26.02 \\
Associate member & 12 & 16.44 & 42.46 \\
MNIQS & 34 & 46.58 & 89.04 \\
FNIQS & 8 & 10.96 & 100.00 \\
Total & $\mathbf{7 3}$ & $\mathbf{1 0 0 . 0 0}$ & \\
& & & \\
\hline
\end{tabular}


Table IV. Drivers to the adoption of BIM based detailed cost estimating in quantity surveying consulting practices

\begin{tabular}{|c|c|c|c|c|c|c|c|c|c|c|}
\hline \multirow[b]{2}{*}{ Factors } & \multicolumn{3}{|c|}{ BIM users } & \multicolumn{3}{|c|}{ Non-BIM users } & \multicolumn{2}{|c|}{ Mann-Whitney } & \multirow{2}{*}{$\begin{array}{l}\text { Total } \\
\text { Mean } \\
\end{array}$} & \multirow{2}{*}{$\begin{array}{l}\text { Total } \\
\text { Rank }\end{array}$} \\
\hline & Mean & SD & Rank & Mean & SD & Rank & Test & Sig. & & \\
\hline 1. Enhanced quality of decision & 4.53 & 0.74 & 2 & 4.40 & 0.72 & 7 & 0.810 & 0.4178 & 4.47 & 3 \\
\hline 2. Visualization & 4.31 & 0.59 & 9 & 4.23 & 0.68 & 10 & 0.618 & 0.5363 & 4.27 & 11 \\
\hline 3. Data coordination & 4.37 & 0.70 & 7 & 4.54 & 0.72 & 2 & -1.173 & 0.2406 & 4.46 & 4 \\
\hline 4. Reliability of estimate & 4.15 & 0.79 & 14 & 4.16 & 0.84 & 15 & -0.053 & 0.9580 & 4.16 & 15 \\
\hline 5. Marketing purpose & 3.47 & 0.78 & 21 & 3.86 & 0.94 & 19 & -1.398 & 0.1621 & 3.67 & 21 \\
\hline \multicolumn{11}{|l|}{ 6. Collaborative working and communication } \\
\hline between stakeholders & 4.16 & 0.96 & 13 & 4.51 & 0.77 & 4 & -1.873 & 0.0611 & 4.34 & 8 \\
\hline 7. Backing for quantity surveyor tasks & 4.34 & 0.87 & 8 & 4.43 & 0.72 & 5 & -0.684 & 0.4942 & 4.39 & 6 \\
\hline 8. Cost saving in preparation of detailed estimate & 4.46 & 0.79 & 5 & 4.30 & 0.96 & 9 & 0.889 & 0.3740 & 4.38 & 7 \\
\hline 9. Time saving in preparation of detailed estimate & 4.50 & 0.71 & 3 & 4.52 & 0.72 & 3 & -0.220 & 0.8257 & 4.51 & 2 \\
\hline 10. Increase profitability & 4.10 & 0.83 & 17 & 4.00 & 0.94 & 17 & 0.707 & 0.4797 & 4.05 & 18 \\
\hline 11. Automation of quantities & 4.72 & 0.72 & 1 & 4.71 & 0.53 & 1 & 0.395 & 0.6928 & 4.72 & 1 \\
\hline 12. Government pressure towards better practices & 4.02 & 0.97 & 19 & 3.84 & 1.12 & 20 & 1.038 & 0.2992 & 3.93 & 19 \\
\hline 13. Client and competitive pressure & 4.16 & 0.64 & 13 & 3.97 & 0.81 & 18 & 1.458 & 0.1448 & 4.07 & 17 \\
\hline \multicolumn{11}{|l|}{ 14. Streamlining design activities and improving } \\
\hline design quality & 4.44 & 0.86 & 6 & 4.36 & 0.92 & 8 & 0.581 & 0.5615 & 4.40 & 5 \\
\hline \multirow{2}{*}{$\begin{array}{l}\text { 15. Desire for innovation to remain competitive } \\
\text { 16. Improving the capacity to provide whole life value } \\
\text { to client }\end{array}$} & 4.13 & 0.65 & 15 & 4.17 & 0.79 & 14 & -0.031 & 0.9755 & 4.15 & 16 \\
\hline & 417 & 074 & 12 & 422 & 084 & 12 & - 286 & 07750 & 420 & 13 \\
\hline \multicolumn{11}{|l|}{ 17. Increased efficiency in monitoring with reduction } \\
\hline of requests for information & 4.26 & 0.68 & 11 & 4.41 & 0.94 & 6 & -0.721 & 0.4709 & 4.34 & 8 \\
\hline \multirow{2}{*}{$\begin{array}{l}\text { 18. Reduces variability in cost estimate } \\
\text { 19. Accurate construction sequencing and clash } \\
\text { detection }\end{array}$} & 4.27 & 0.74 & 10 & 4.14 & 0.84 & 16 & 0.745 & 0.4563 & 4.21 & 12 \\
\hline & 4.50 & 0.83 & 4 & 4.18 & 0.95 & 13 & 1.587 & 0.1125 & 4.34 & 8 \\
\hline \multirow{3}{*}{$\begin{array}{l}\text { 20. It allows precise future prediction of construction } \\
\text { costs } \\
\text { 21. Facilitating increased prefabrication with } \\
\text { information rich BIM }\end{array}$} & & & & & & & & & & \\
\hline & 4.13 & 0.72 & 18 & 4.23 & 0.90 & 11 & -0.364 & 0.7156 & 4.18 & 14 \\
\hline & 3.96 & 0.83 & 20 & 3.80 & 0.86 & 21 & 0.767 & 0.4431 & 3.88 & 20 \\
\hline
\end{tabular}

Note: significant at 5\%; SD-standard deviation 
Table V. KMO and Bartlett's test

\begin{tabular}{lrr}
\hline Kaiser-Meyer-Olkin Measure of Sampling Adequacy. & 0.849 \\
Bartlett's Test of Sphericity & Approx. Chi-Square & 919.433 \\
& Df & 210 \\
Sig. & 0.000
\end{tabular}

Table VI. Principal factor extraction, varimax rotation and total variance explained on drivers to the adoption of BIM for detailed cost estimating

\begin{tabular}{|c|c|c|c|c|}
\hline \multirow[t]{2}{*}{ Factor } & \multicolumn{4}{|c|}{ Initial eigenvalues } \\
\hline & $\begin{array}{l}\text { Factor } \\
\text { loadings }\end{array}$ & Total & $\begin{array}{l}\% \text { of } \\
\text { variance } \\
\text { explained }\end{array}$ & $\begin{array}{l}\text { Cumulative } \\
\% \text { of } \\
\text { variance } \\
\text { explained }\end{array}$ \\
\hline
\end{tabular}

Factor 1: Improved whole life cycle and improved design quality

Improving the capacity to provide whole life value to client

Streamlining design activities and improving design 0.790

quality

Increased efficiency in monitoring with reduction of 0.757

requests for information

It allows precise future prediction of construction costs $\quad 0.747$

Accurate construction sequencing and clash detection $\quad 0.719$

Desire for innovation to remain competitive 0.694

Increase profitability $\quad 0.641$

Reliability of estimate 0.639

Client and competitive pressure $\quad 0.624$

Reduces variability in cost estimate $\quad 0.613$

Collaborative working and communication between 0.415

stakeholders

Factor 2: Enhanced decision and visualization

Enhanced quality of decision $\quad 0.831$

$5.961 \quad 28.388$

28.388

Visualization

Data coordination

Automation of quantities

0.746

0.698

0.503

Factor 3:Cost and time saving in preparation of detailed cost estimate

Cost saving in preparation of detailed estimate

$\begin{array}{lll}0.848 & 2.836 \quad 13.506\end{array}$

55.763

Time saving in preparation of detailed estimate

0.679

Factor 4: Marketing and support for quantity surveyor task

Backing for quantity surveyor tasks ( i.e. Support for quantity surveyor at times when many projects are at hand) Marketing purpose

Factor 5: Government and client pressure

Government pressure towards better practices

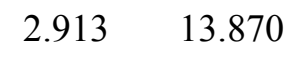

42.258

Facilitating increased prefabrication with information rich

0.755

$2.354 \quad 11.208$

66.971

BIM

Extraction Method: Principal Component Analysis

Rotation Method: Varimax with Kaiser Normalization

Rotation converged in 14 iterations 